\title{
UK Renal Registry 18th Annual Report: Chapter 7 Adequacy of Haemodialysis in UK Adult Patients in 2014: National and Centre-specific Analyses
}

Andrew Davenport ${ }^{\mathrm{a}}$, Catriona Shaw ${ }^{\mathrm{b}}$, Retha Steenkamp ${ }^{\mathrm{c}}$

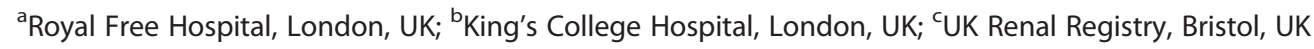

\section{Key Words}

Adequacy · Haemodialysis . Urea reduction ratio

\section{Summary}

- Data suitable for urea reduction ratio (URR) analyses were available for 14,761 (71.9\%) of the 20,539 patients receiving haemodialysis (HD) in the UK on the $30 / 9 / 2014$.

- In $2014,88.6 \%$ of prevalent HD patients achieved a URR $>65 \%$. The between centre range of prevalent patients achieving this target was wide (74.997.0\%).

- The median URR in 2014 was $75 \%$.

- URR was greater in those with longer dialysis vintage, with $91.2 \%$ of patients who had survived on renal replacement therapy (RRT) for more than two years achieving a URR $>65 \%$ compared with only $73.4 \%$ of those on RRT for less than six months.

- Large variation between centres in the percentage of patients achieving the UK Renal Association's (RA) URR guideline persists.
C 2016 The UK Renal Registry Published by S. Karger AG, Basel $1660-8151 / 16 / 1325-0155 \$ 39.50 / 0$

Karger Open access

This article is licensed under the Creative Commons AttributionNonCommercial-NoDerivatives 4.0 International License (CC BY NC-ND) (http://www.karger.com/Services/OpenAccessLicense). Usage and distribution for commercial purposes as well as any distribution of modified material requires written permission.
Andrerw Davenport

UK Renal Registry, Southmead Hospital, Southmead Road, Bristol, BS10 5NB, UK

Email: renalregistry@renalregistry.nhs.uk 


\section{Introduction}

The UK Renal Registry (UKRR) started collecting data from dialysis centres in England, Wales and Northern Ireland approximately 20 years ago. At that time haemodialysis facilities were limited, and one of the objectives of the UKRR, in collaboration with the UK Renal Association was to provide data on haemodialysis provision, and quality metrics compared to clinical standards set by the Renal Association [1], designed to establish parity between centres and improve provision and delivery of treatments.

The traditional paradigm for determining haemodialysis adequacy is based on sessional urea clearance, and both prospective and observational studies have reported an association between urea clearance and patient outcomes $[2,3]$. The delivered dose of HD depends on both treatment factors (duration and frequency of dialysis sessions, dialyser size and characteristics, dialysate and blood flow rate) and patient characteristics (including size, protein intake, physical activity, haematocrit and vascular access) [4]. The most widely accepted measures of urea clearance are $\mathrm{Kt} / \mathrm{V}$, the ratio between the product of urea clearance $(\mathrm{K}$, in $\mathrm{ml} / \mathrm{min})$ and dialysis session duration ( $t$, in minutes) divided by the volume of distribution of urea in the body $(\mathrm{V}$, in $\mathrm{ml}$ ) and urea reduction ratio, which is derived solely from the percentage fall in serum urea during a dialysis treatment. Whilst $\mathrm{Kt} / \mathrm{V}$ is a more accurate descriptor of urea clearance, its calculation is more complex and requires additional data items not commonly reported by most UK renal centres [5-7].
The UKRR has historically presented analyses based on URR rather than Kt/V for comparative audit of haemodialysis adequacy as these data are more widely available. On one hand, URR does not take into account the rebound in serum urea concentration at the end of dialysis, and so may over estimate delivered dialysis dose, particularly when higher blood pump speeds are used, whereas on the other hand URR does not include any estimate of residual renal function (RRF).

Clinical practice guidelines have been developed by various national and regional organisations $[1,8,9]$, with considerable uniformity to the minimum dose of dialysis recommended, although there are differences in the methodology advised. Table 7.1 outlines the recommended UK RA audit measures for haemodialysis patients and whether the audit measure is currently reported in the annual UKRR report [1].

The objective of this chapter is to determine haemodialysis practice patterns in the $\mathrm{UK}$, and the extent to which patients undergoing $\mathrm{HD}$ treatment received the dose of $\mathrm{HD}$, as measured by URR, recommended by the current UK RA clinical practice guidelines [1].

\section{Methods}

Seventy-one renal centres in the UK submitted data electronically to the UKRR on a quarterly basis. The majority of these centres have satellite units but for the purposes of this study the data from the renal centres and their associated satellite units were amalgamated. Data from two groups of patients were

Table 7.1 Summary of recommended Renal Association audit measures relevant to haemodialysis adequacy [1]

\begin{tabular}{lcc}
\hline RA audit measure & $\begin{array}{c}\text { Included in UKRR } \\
\text { annual report? }\end{array}$ & Reason for non-inclusion \\
\hline
\end{tabular}

Haemodialysis adequacy audit measures

Audit measure: The proportion of patients in the main renal centre and its satellite units who are on twice weekly haemodialysis

Audit measure: Cumulative frequency curves of urea reduction ratio measured using a standard method of post-dialysis sampling

Audit measure: The proportion of patient non-attendances for haemodialysis sessions and the proportion of dialysis sessions shortened at the patient's request

Audit measure: The proportion of thrice weekly haemodialysis sessions No which have prescribed treatment times less than 4 hours

Audit measure: The proportion of hospital (main and satellite unit) and home haemodialysis patients who are prescribed more frequent than thrice weekly haemodialysis
No

Yes, but data not presented in the cumulative frequency format

No Data not available

Yes
Varying levels of reporting between centres

Varying levels of reporting between centres

Not for home

haemodialysis patients 
analysed. Firstly, analysis was undertaken using data from the prevalent adult HD patient population as of the 30th September 2014. For this analysis, data for URR were taken from the 3rd quarter of 2014 unless that data point was missing in which case data from the 2 nd quarter were taken. The prevalent population only included patients receiving HD who were alive on September 30th 2014. Data from those patients who had died before that date have not been included in the analysis. The second analysis involved adult incident patients who had commenced treatment with HD during 2013. For these patients, analysis was undertaken using the last recorded URR in the quarter in which the patient had started dialysis. The incident HD patient cohort was followed up for one year and the last recorded URR in the quarter after one year follow-up was used for this analysis.

Data from patients known to be receiving more or less than thrice weekly HD were omitted from the analysis for both the incident and prevalent population. Patients for whom data recording the number of dialysis sessions per week were missing, were assumed to be dialysing thrice weekly. However, because not all centres report frequency of $\mathrm{HD}$, it is possible that data from a small number of patients receiving HD at a different frequency were included in the analyses. Home HD patients were excluded from the analysis.

Analyses of the data from both groups of patients included the calculation of the median URR and of the proportion of patients who had achieved the RA guideline (as outlined below) in each of the renal centres as well as for the country as a whole. The median URR and proportion of patients who achieved the RA guideline were also calculated separately for males and females. The number of dialysis sessions per week and the time per dialysis session is shown by renal centre.

All patients with data were included in the statistical analyses at a national level, although centres with fewer than 20 patients, or providing less than $50 \%$ data completeness were excluded from the comparison between centres. The number preceding the centre name in each figure indicates the percentage of missing data for that centre.

The UK RA clinical practice guidelines in operation at the time these data were collected were as follows:

HD should take place at least three times per week in nearly all patients. Reduction of dialysis frequency to twice per week because of insufficient dialysis facilities is unacceptable.

Every patient receiving thrice weekly $H D$ should have consistently:

- either URR >65\%

- or equilibrated $\mathrm{Kt} / \mathrm{V}(\mathrm{eKt} / \mathrm{V})$ of $>1.2$ (or single pool $\mathrm{Kt} / \mathrm{V}$ of $>1.3)$ calculated from pre- and post-dialysis urea values, duration of dialysis and weight loss during dialysis).

To achieve a URR above $65 \%$ or eKt/V above 1.2 consistently in the vast majority of the HD population clinicians should aim for a minimum target URR of $70 \%$ or minimum $e K t / V$ of 1.4 in individual patients.

The duration of thrice weekly HD in adult patients with minimal residual renal function should not be reduced below 4 hours without careful consideration.

Patients receiving HD twice weekly for reasons of geography should receive a higher sessional dose of $H D$. If this cannot be achieved, then it should be recognised that there is a compromise between the practicalities of $H D$ and the patient's long-term health.

Measurement of the 'dose' or 'adequacy' of HD should be performed monthly in all hospital HD patients and may be performed less frequently in home HD patients. All dialysis units should collect and report this data to their regional network and the UKRR.

Post-dialysis blood samples should be collected either by the slow-flow method, the simplified stop-flow method, or the stop dialysate flow method. The method used should remain consistent within renal units and should be reported to the Registry.

The RA clinical practice guidelines for HD dose apply specifically to patients undergoing thrice weekly HD. In these patients it is recommended that blood for biochemical measurement (including pre-dialysis urea for URR) should be taken before the mid-week dialysis session [1].

\section{Results}

\section{Data completeness}

Sixty four of the 71 renal centres submitted HD dose (URR) data to the UKRR (table 7.2). Data were available for $71.9 \%(N=14,761)$ of the total prevalent population $(N=20,539)$ treated with HD who met the inclusion criteria for these analyses.

Fifty centres reported URR data on more than $90 \%$ of patients. Thirteen centres reported URR data on less than $50 \%$ of prevalent patients (Carshalton, Manchester RI, Newcastle, Reading, Brighton, Sunderland), with no URR data received from seven centres (London Barts, London King's, London Royal Free, London St Georges, Liverpool Aintree, Liverpool Royal Infirmary, Wirral).

Several centres had a reduction in the completeness of URR data submitted to the UKRR in 2014 compared with 2013 (data not shown). These changes may represent changes in data extraction, or a move by centres to utilising $\mathrm{Kt} / \mathrm{V}$ rather than URR as the preferred measure of dialysis dose.

Of the total incident patient population $(N=4,404)$ who started HD during 2013 and meeting the inclusion criteria for URR analyses, 48.5\% $(N=2,137)$ had URR data available during the first quarter of treatment (data not shown).

Data completeness on the number of HD sessions per week varied between centres (table 7.3). Seven centres in England and four centres in Wales returned no data. All centres in Northern Ireland returned data for $100 \%$ of their HD population. All centres in Scotland returned data in over $95 \%$ of their HD population. 
Table 7.2. Percentage completeness of URR data returns for prevalent patients on HD by centre, on 30/9/2014

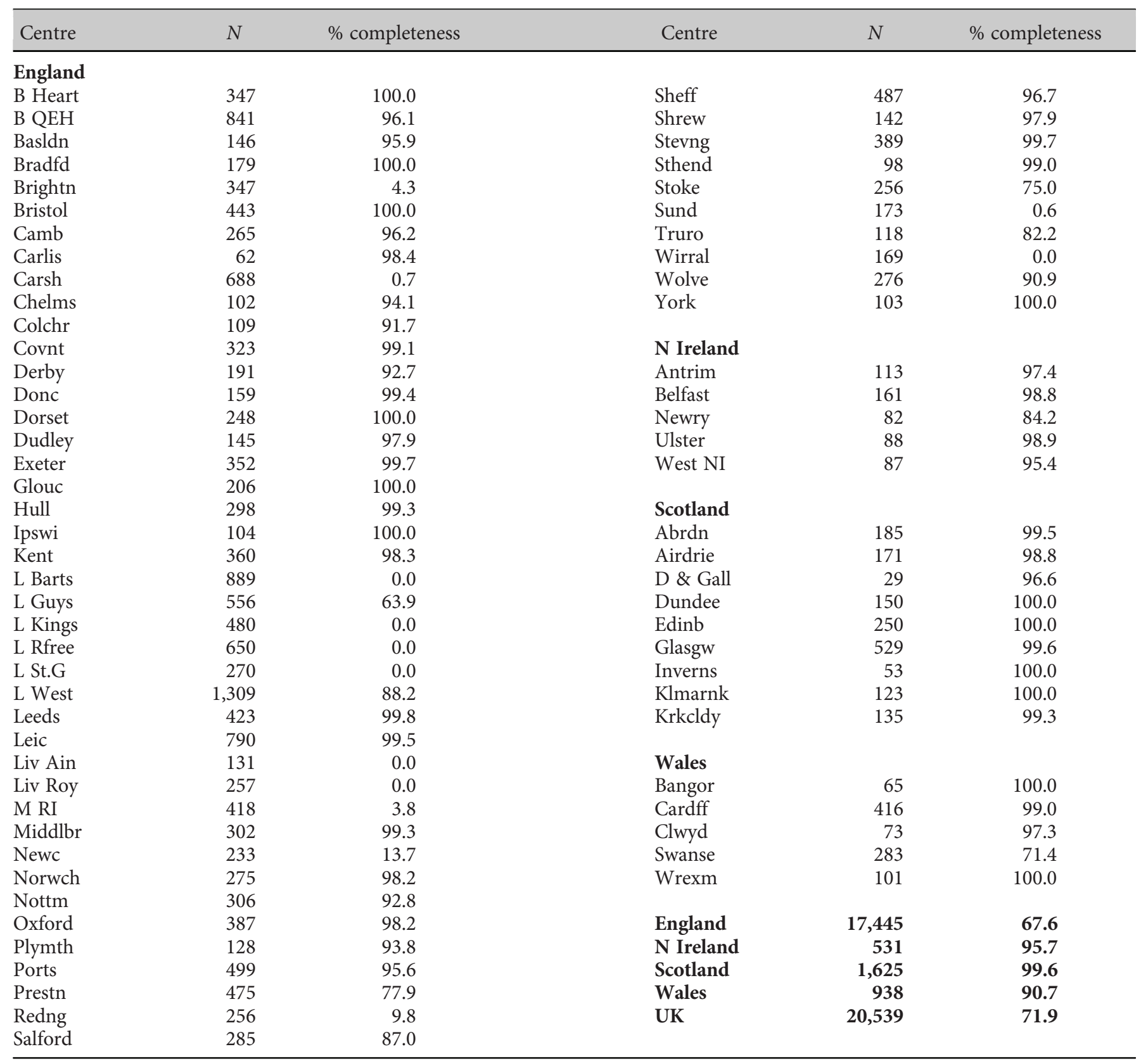

For those centres returning data, three dialysis sessions a week was most prevalent, although a few centres reported $>10 \%$ of HD patients receiving more or less than thrice weekly treatments (table 7.3). For example, Salford reported $20.1 \%$ of patients receiving more than three sessions a week, whereas Southend reported $14.0 \%$ of patients having less than three sessions per week.

Again there was a wide variation between centres in completeness of data on dialysis session time (table 7.4). The great majority of prevalent patients dialysed between
3.5-5.0 hours, although there was variation. Taking centres with $99 \%$ or greater data completion for time per dialysis session, then London King's reported $16.3 \%$ of patients dialysing $<3.5$ hours per session, and Newcastle reported dialysing $1.3 \%$ of patients for more than five hours per session.

\section{Achieved URR}

The UK median URR reported for prevalent HD patients was $75.0 \%$ (centre range 71.0-82.5\%) (figure 7.1a), with a 
Table 7.3. Number of dialysis sessions for prevalent patients on HD by centre, on 30/9/2014

\begin{tabular}{|c|c|c|c|c|c|}
\hline \multirow[b]{2}{*}{ Centre } & \multirow[b]{2}{*}{$N$} & \multirow{2}{*}{$\begin{array}{l}\text { Percentage } \\
\text { completeness }\end{array}$} & \multicolumn{3}{|c|}{ Percentage } \\
\hline & & & $<3$ sessions & 3 sessions & $>3$ sessions \\
\hline \multicolumn{6}{|l|}{ England } \\
\hline B Heart & 381 & 83.7 & 8.8 & 89.3 & 1.9 \\
\hline B QEH & 841 & 0.0 & & & \\
\hline Basldn & 152 & 98.7 & 0.0 & 96.0 & 4.0 \\
\hline Bristol & 471 & 100.0 & 4.0 & 94.1 & 1.9 \\
\hline Camb & 298 & 98.7 & 9.2 & 88.8 & 2.0 \\
\hline Carlis & 65 & 96.9 & 4.8 & 95.2 & 0.0 \\
\hline Carsh & 693 & 99.3 & 0.4 & 99.3 & 0.3 \\
\hline Chelms & 115 & 99.1 & 9.6 & 88.6 & 1.8 \\
\hline Dorset & 252 & 99.2 & 1.2 & 98.4 & 0.4 \\
\hline Dudley & 148 & 99.3 & 1.4 & 98.0 & 0.7 \\
\hline Exeter & 375 & 99.7 & 4.5 & 93.9 & 1.6 \\
\hline Glouc & 206 & 0.0 & & & \\
\hline Hull & 298 & 1.0 & & & \\
\hline Ipswi & 110 & 76.4 & 6.0 & 92.9 & 1.2 \\
\hline Kent & 378 & 99.2 & 3.2 & 95.2 & 1.6 \\
\hline L Barts & 889 & 0.0 & & & \\
\hline L Guys & 556 & 0.0 & & & \\
\hline L Kings & 480 & 100.0 & 0.0 & 100.0 & 0.0 \\
\hline L Rfree & 650 & 0.0 & & & \\
\hline L St.G & 272 & 90.1 & 0.8 & 99.2 & 0.0 \\
\hline Newc & 237 & 100.0 & 0.4 & 98.3 & 1.3 \\
\hline Norwch & 281 & 99.6 & 1.4 & 97.9 & 0.7 \\
\hline Nottm & 310 & 99.0 & 1.3 & 98.7 & 0.0 \\
\hline Oxford & 387 & 100.0 & 0.0 & 100.0 & 0.0 \\
\hline Plymth & 128 & 0.0 & & & \\
\hline Ports & 541 & 98.5 & 6.0 & 92.1 & 1.9 \\
\hline Prestn & 475 & 0.0 & & & \\
\hline Redng & 259 & 98.8 & 0.4 & 98.8 & 0.8 \\
\hline Salford & 360 & 99.7 & 0.8 & 79.1 & 20.1 \\
\hline Sheff & 510 & 99.8 & 4.5 & 95.5 & 0.0 \\
\hline Shrew & 153 & 100.0 & 5.2 & 92.8 & 2.0 \\
\hline Stevng & 421 & 99.3 & 5.5 & 92.3 & 2.2 \\
\hline Sthend & 114 & 100.0 & 14.0 & 86.0 & 0.0 \\
\hline Stoke & 267 & 99.6 & 0.8 & 95.9 & 3.4 \\
\hline Sund & 190 & 96.8 & 0.0 & 90.8 & 9.2 \\
\hline Truro & 130 & 90.0 & 7.7 & 89.7 & 2.6 \\
\hline Wirral & 187 & 98.9 & 1.1 & 90.3 & 8.6 \\
\hline Wolve & 276 & 7.6 & & & \\
\hline York & 112 & 97.3 & 0.9 & 91.7 & 7.3 \\
\hline
\end{tabular}


Table 7.3. Continued

\begin{tabular}{|c|c|c|c|c|c|}
\hline \multirow[b]{2}{*}{ Centre } & \multirow[b]{2}{*}{$N$} & \multirow{2}{*}{$\begin{array}{l}\text { Percentage } \\
\text { completeness }\end{array}$} & \multicolumn{3}{|c|}{ Percentage } \\
\hline & & & $<3$ sessions & 3 sessions & $>3$ sessions \\
\hline \multicolumn{6}{|l|}{ N Ireland } \\
\hline Antrim & 114 & 100.0 & 0.0 & 99.1 & 0.9 \\
\hline Belfast & 168 & 100.0 & 0.6 & 95.8 & 3.6 \\
\hline Newry & 86 & 100.0 & 4.7 & 95.3 & 0.0 \\
\hline Ulster & 91 & 100.0 & 1.1 & 96.7 & 2.2 \\
\hline West NI & 99 & 100.0 & 2.0 & 87.9 & 10.1 \\
\hline \multicolumn{6}{|l|}{ Scotland } \\
\hline Abrdn & 196 & 100.0 & 1.5 & 94.4 & 4.1 \\
\hline Airdrie & 171 & 97.1 & 0.0 & 100.0 & 0.0 \\
\hline D \& Gall & 41 & 100.0 & 4.9 & 70.7 & 24.4 \\
\hline Dundee & 153 & 99.4 & 0.0 & 98.0 & 2.0 \\
\hline Edinb & 251 & 99.6 & 0.4 & 99.6 & 0.0 \\
\hline Glasgw & 533 & 95.5 & 0.6 & 99.2 & 0.2 \\
\hline Inverns & 56 & 100.0 & 0.0 & 94.6 & 5.4 \\
\hline Klmarnk & 123 & 98.4 & 0.0 & 100.0 & 0.0 \\
\hline Krkcldy & 136 & 97.8 & 0.8 & 99.2 & 0.0 \\
\hline \multicolumn{6}{|l|}{ Wales } \\
\hline Bangor & 65 & 0.0 & & & \\
\hline Cardff & 416 & 0.0 & & & \\
\hline Clwyd & 79 & 94.9 & 1.3 & 92.0 & 6.7 \\
\hline Swanse & 283 & 0.0 & & & \\
\hline Wrexm & 101 & 0.0 & & & \\
\hline England & 18,018 & 65.4 & 2.7 & 95.1 & 2.1 \\
\hline N Ireland & 558 & 100.0 & 1.4 & 95.2 & 3.4 \\
\hline Scotland & 1,660 & 97.8 & 0.6 & 97.8 & 1.5 \\
\hline Wales & 944 & 7.9 & & & \\
\hline UK & 21,180 & 66.3 & 2.4 & 95.4 & 2.2 \\
\hline
\end{tabular}

Blank cells denote no data returned by that centre or data not shown due to $<50 \%$ data completeness

median URR for women of $78.0 \%$ (centre range 71.0 $87.0 \%$ ) compared with a median for men of $74.0 \%$ (centre range $69.0-81.0 \%$ ) (figures $7.1 \mathrm{~b}, 7.1 \mathrm{c}$ ). The percentage of patients achieving the UK RA guideline of a URR $>65 \%$ was $88.6 \%$ for the UK, with a centre range of 74.9 $97.0 \%$ (figure 7.2 ). There continued to be variation between renal centres in the percentage of prevalent patients with a URR of $>65 \%$, with 23 centres attaining the UK RA clinical practice guideline for $>90 \%$ of patients and 34 centres reporting a URR of $>65 \%$ in $75-90 \%$ of patients (figure 7.2). The percentage of prevalent male HD patients achieving the URR target was $86.5 \%$ for the UK, with a centre range of $64.7-96.2 \%$, compared to $92.0 \%$ for prevalent female HD patients, with a centre range of $73.6-100 \%$.

\section{Changes in URR over time}

The proportion of patients attaining the UK RA guideline (sessional URR >65\%) increased from $70.7 \%$ to
88.6\% from 2001-2014, whilst the median URR has risen from $70.0 \%$ to $75.0 \%$ during the same time period (figure 7.3). However, between 2011 and 2014, there has been no substantial increase in median URR reported by centres in the UK, or in the percentage of patients achieving the UK RA target.

\section{Variation of achieved URR with time on dialysis}

The proportion of prevalent HD patients who attained the UK RA clinical guideline for sessional URR was greatest for those who had been on dialysis for the longest time (figure 7.4). In 2014, 73.4\% of those dialysed for less than six months had a URR $>65 \%$, whilst $91.2 \%$ of patients who had survived and continued on RRT for more than two years had a URR within the guideline target. In all strata of time on dialysis, there has been an improvement in the proportion of patients receiving the target dose between 2000-2011, thereafter there has been no substantial increase. 
Table 7.4. Time per dialysis session for prevalent patients on HD by centre, on 30/9/2014

\begin{tabular}{|c|c|c|c|c|c|}
\hline Centre & $N$ & $\begin{array}{c}\text { Percentage } \\
\text { completeness }\end{array}$ & $<3.5$ hours & 3.5-5 hours & $5+$ hours \\
\hline B Heart & 347 & 76.7 & 4.5 & 95.1 & 0.4 \\
\hline B QEH & 841 & 0.0 & & & \\
\hline Basldn & 146 & 98.6 & 11.8 & 88.2 & 0.0 \\
\hline Bristol & 443 & 100.0 & 5.6 & 94.4 & 0.0 \\
\hline Camb & 265 & 0.0 & & & \\
\hline Carlis & 62 & 96.8 & 5.0 & 95.0 & 0.0 \\
\hline Carsh & 688 & 97.7 & 1.8 & 98.2 & 0.0 \\
\hline Chelms & 102 & 99.0 & 5.9 & 94.1 & 0.0 \\
\hline Dorset & 248 & 99.2 & 2.8 & 97.2 & 0.0 \\
\hline Dudley & 145 & 99.3 & 8.3 & 91.7 & 0.0 \\
\hline Exeter & 352 & 100.0 & 19.0 & 81.0 & 0.0 \\
\hline Glouc & 206 & 0.0 & & & \\
\hline Hull & 298 & 2.3 & & & \\
\hline Ipswi & 104 & 75.0 & 2.6 & 97.4 & 0.0 \\
\hline Kent & 360 & 99.7 & 17.0 & 83.0 & 0.0 \\
\hline L Barts & 889 & 0.0 & & & \\
\hline L Guys & 556 & 14.2 & & & \\
\hline L Kings & 480 & 100.0 & 16.3 & 83.8 & 0.0 \\
\hline L Rfree & 650 & 0.0 & & & \\
\hline L St.G & 270 & 80.0 & 1.4 & 98.6 & 0.0 \\
\hline Newc & 233 & 99.6 & 6.0 & 92.7 & 1.3 \\
\hline Norwch & 275 & 99.6 & 16.1 & 83.9 & 0.0 \\
\hline Nottm & 306 & 99.0 & 6.6 & 93.1 & 0.3 \\
\hline Oxford & 387 & 100.0 & 8.3 & 91.5 & 0.3 \\
\hline Plymth & 128 & 0.0 & & & \\
\hline Ports & 499 & 0.0 & & & \\
\hline Prestn & 475 & 0.4 & & & \\
\hline Redng & 256 & 94.1 & 0.8 & 99.2 & 0.0 \\
\hline Salford & 285 & 94.4 & 6.3 & 93.3 & 0.4 \\
\hline Sheff & 487 & 86.2 & 50.2 & 49.3 & 0.5 \\
\hline Shrew & 142 & 100.0 & 12.7 & 87.3 & 0.0 \\
\hline Stevng & 389 & 99.7 & 33.5 & 66.5 & 0.0 \\
\hline Sthend & 98 & 100.0 & 26.5 & 73.5 & 0.0 \\
\hline Stoke & 256 & 100.0 & 5.5 & 94.5 & 0.0 \\
\hline Sund & 173 & 85.0 & 7.5 & 92.5 & 0.0 \\
\hline Truro & 118 & 94.1 & 18.9 & 80.2 & 0.9 \\
\hline Wirral & 169 & 100.0 & 17.8 & 81.7 & 0.6 \\
\hline Wolve & 276 & 7.6 & & & \\
\hline York & 103 & 99.0 & 2.0 & 98.0 & 0.0 \\
\hline
\end{tabular}


Table 7.4. Continued

\begin{tabular}{|c|c|c|c|c|c|}
\hline \multirow[b]{2}{*}{ Centre } & \multirow[b]{2}{*}{$N$} & \multirow{2}{*}{$\begin{array}{l}\text { Percentage } \\
\text { completeness }\end{array}$} & \multicolumn{3}{|c|}{ Percentage per dialysis session } \\
\hline & & & $<3.5$ hours & $3.5-5$ hours & $5+$ hours \\
\hline \multicolumn{6}{|l|}{ N Ireland } \\
\hline Antrim & 113 & 100.0 & 1.8 & 98.2 & 0.0 \\
\hline Belfast & 161 & 100.0 & 9.3 & 90.7 & 0.0 \\
\hline Newry & 82 & 100.0 & 9.8 & 90.2 & 0.0 \\
\hline Ulster & 88 & 100.0 & 3.4 & 96.6 & 0.0 \\
\hline West NI & 87 & 100.0 & 17.2 & 82.8 & 0.0 \\
\hline \multicolumn{6}{|l|}{ Scotland } \\
\hline Abrdn & 185 & 98.9 & 1.1 & 97.3 & 1.6 \\
\hline Airdrie & 171 & 95.3 & 5.5 & 93.9 & 0.6 \\
\hline D \& Gall & 29 & 82.8 & 0.0 & 95.8 & 4.2 \\
\hline Dundee & 150 & 99.3 & 3.4 & 96.6 & 0.0 \\
\hline Edinb & 250 & 99.2 & 9.3 & 89.9 & 0.8 \\
\hline Glasgw & 529 & 94.9 & 1.6 & 93.8 & 4.6 \\
\hline Inverns & 53 & 100.0 & 1.9 & 98.1 & 0.0 \\
\hline Klmarnk & 123 & 90.2 & 0.0 & 100.0 & 0.0 \\
\hline Krkcldy & 135 & 97.8 & 14.4 & 84.8 & 0.8 \\
\hline \multicolumn{6}{|l|}{ Wales } \\
\hline Bangor & 65 & 0.0 & & & \\
\hline Cardff & 416 & 0.0 & & & \\
\hline Clwyd & 73 & 97.3 & 33.8 & 66.2 & 0.0 \\
\hline Swanse & 283 & 0.0 & & & \\
\hline Wrexm & 101 & 0.0 & & & \\
\hline England & 17,445 & 60.3 & 10.6 & 89.1 & 0.3 \\
\hline $\mathrm{N}$ Ireland & 531 & 100.0 & 8.1 & 91.9 & 0.0 \\
\hline Scotland & 1,625 & 96.3 & 4.3 & 93.7 & 2.0 \\
\hline Wales & 938 & 7.6 & & & \\
\hline UK & 20,539 & 61.8 & 9.9 & 89.6 & 0.5 \\
\hline
\end{tabular}

Blank cells denote no data returned by that centre or data not shown due to $<50 \%$ data completeness

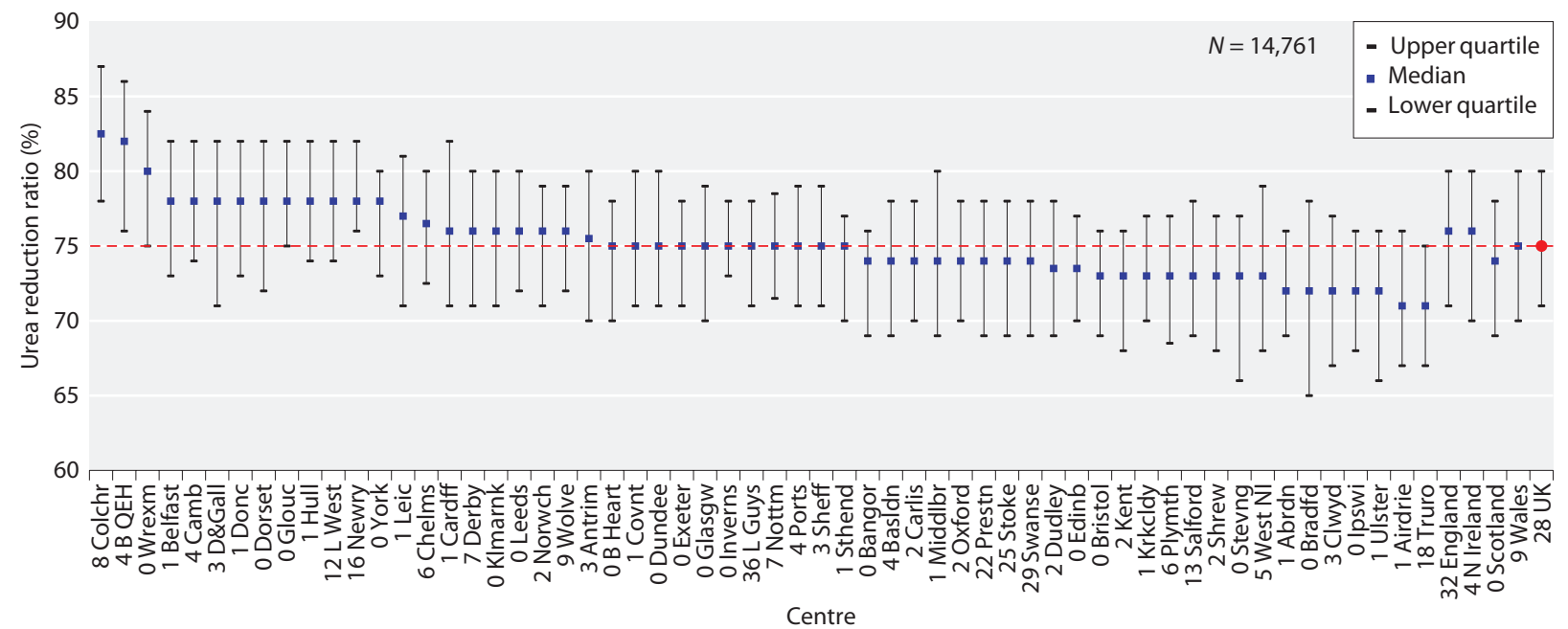

Fig. 7.1a. Median URR achieved in prevalent patients on HD by centre, 30/9/2014 


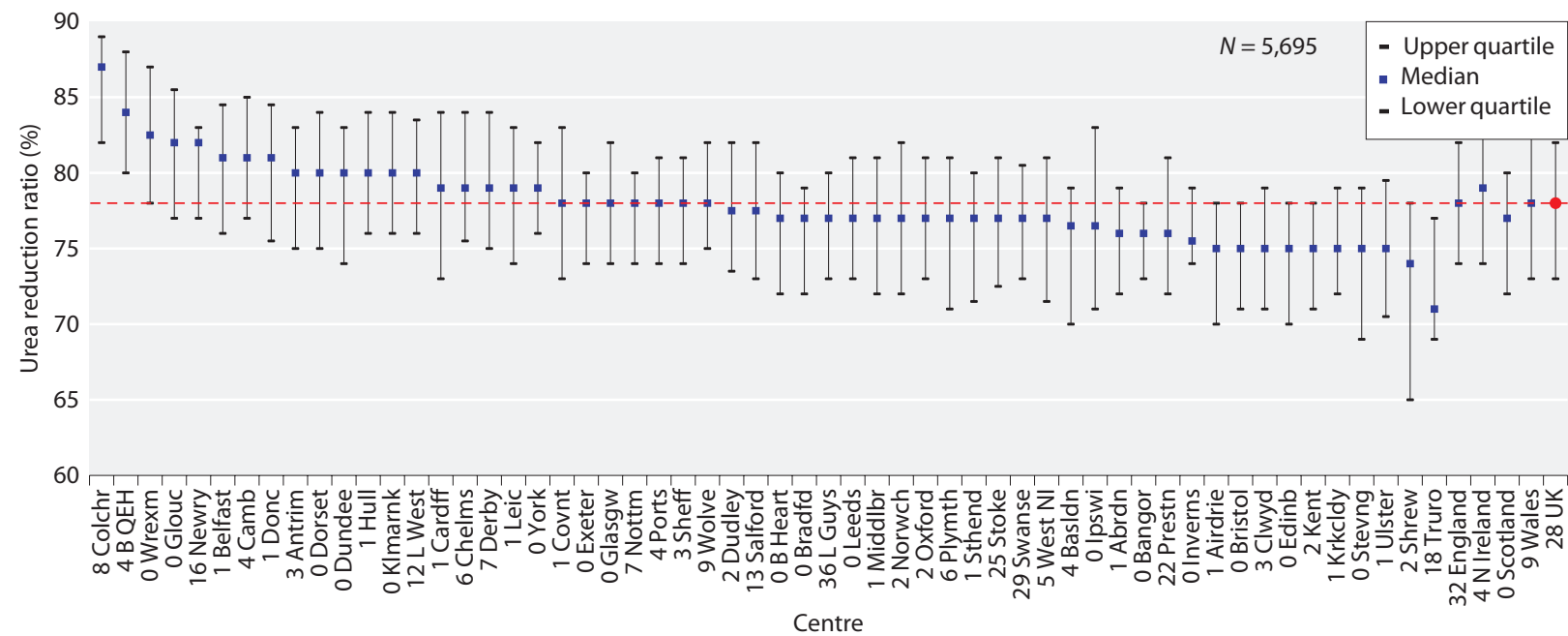

Fig. 7.1b. Median URR achieved in female prevalent patients on HD by centre, 30/9/2014

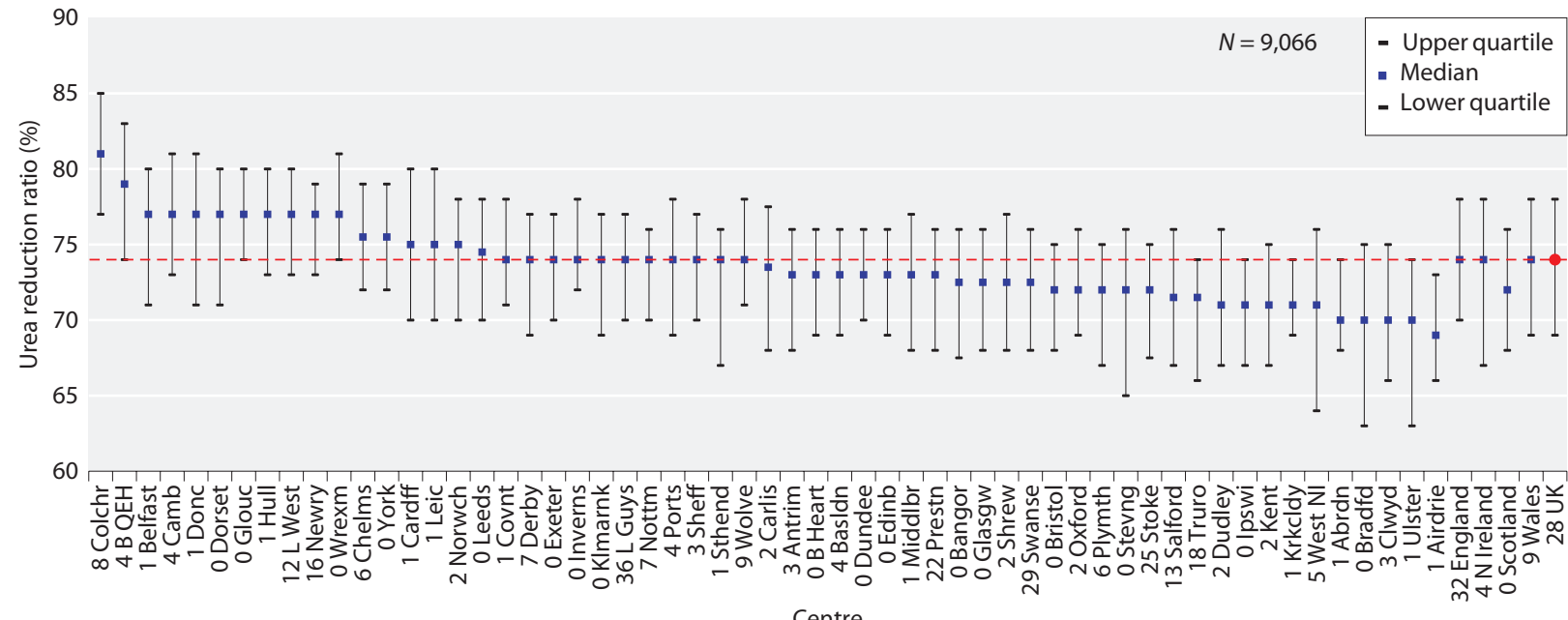

Fig. 7.1c. Median URR achieved in male prevalent patients on HD by centre, 30/9/2014

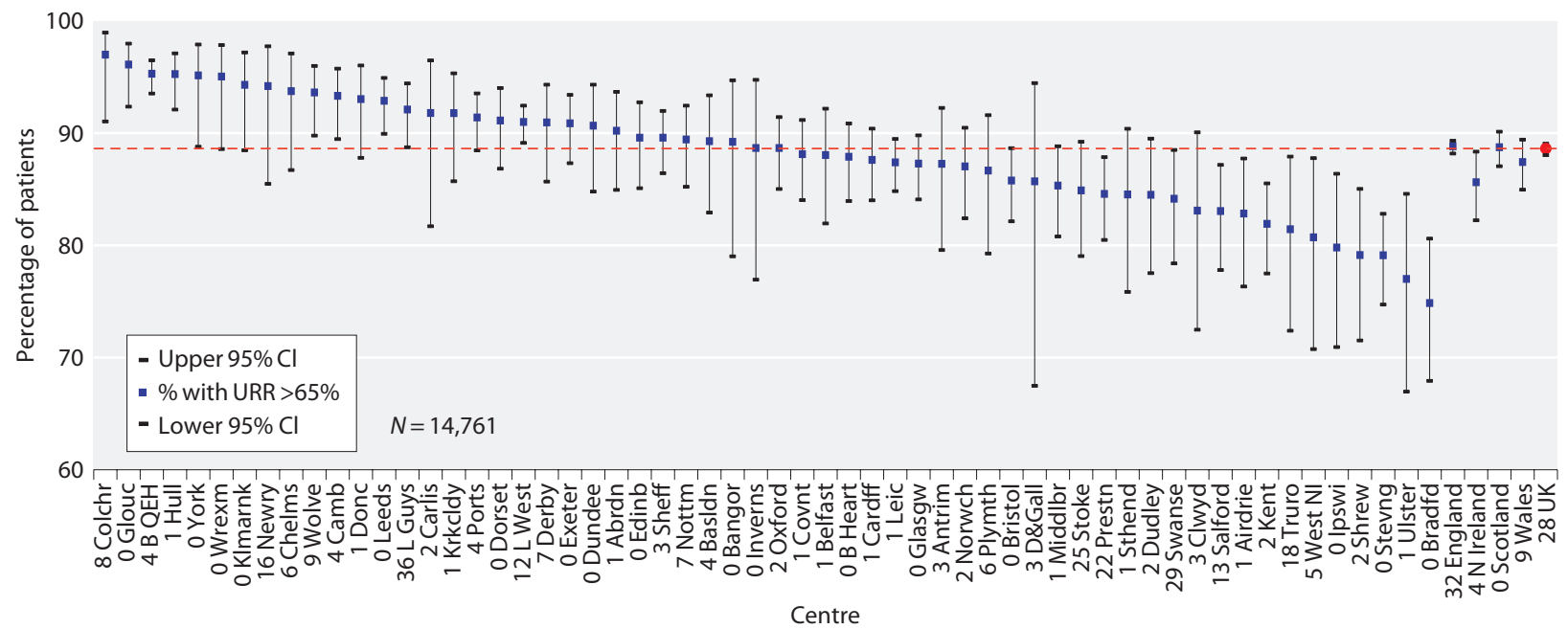

Fig. 7.2. Percentage of prevalent patients on HD with URR $>65 \%$ by centre, $30 / 9 / 2014$ 


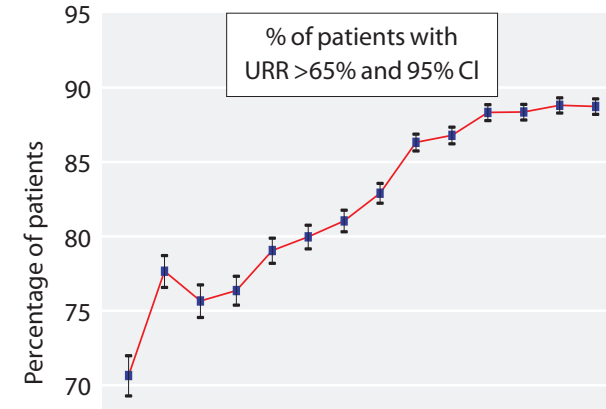

65

60

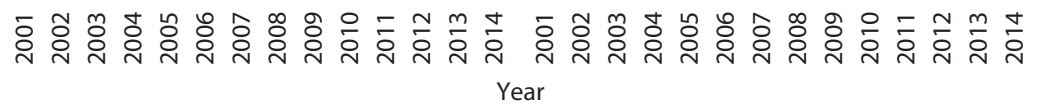

Fig. 7.3. Change in the percentage of prevalent patients on HD with URR $>65 \%$ and the median URR between 2001 and 2014

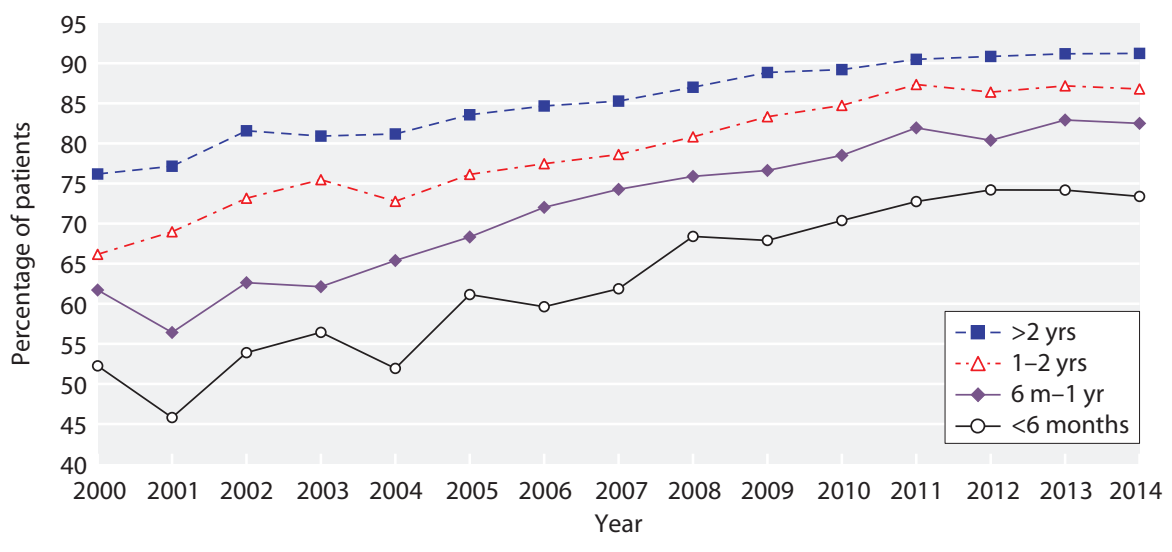

Fig. 7.4. Percentage of prevalent patients on $\mathrm{HD}$ achieving URR $>65 \%$ by time on RRT between 2000 and 2014

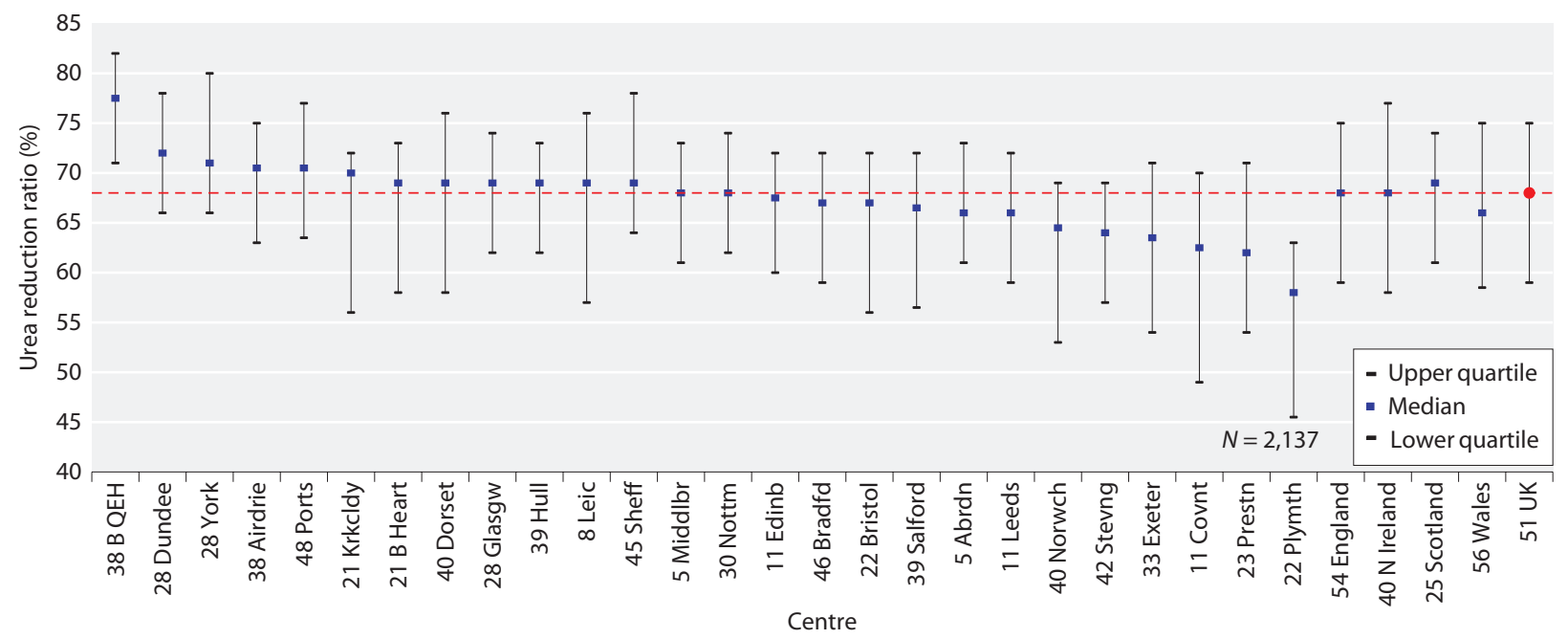

Fig. 7.5a. Median URR in the first quarter of starting RRT in incident patients who started HD in 2013

The median URR during the first quarter after initiating HD treatment of the incident HD population in the UK in 2013 was $68 \%$ (centre range 58.0-77.5\%) (figure 7.5a). At the end of twelve months, the median URR for this incident cohort was higher (median URR $74 \%$, centre range $70-81 \%$ ) (figure $7.5 \mathrm{~b}$ ). 


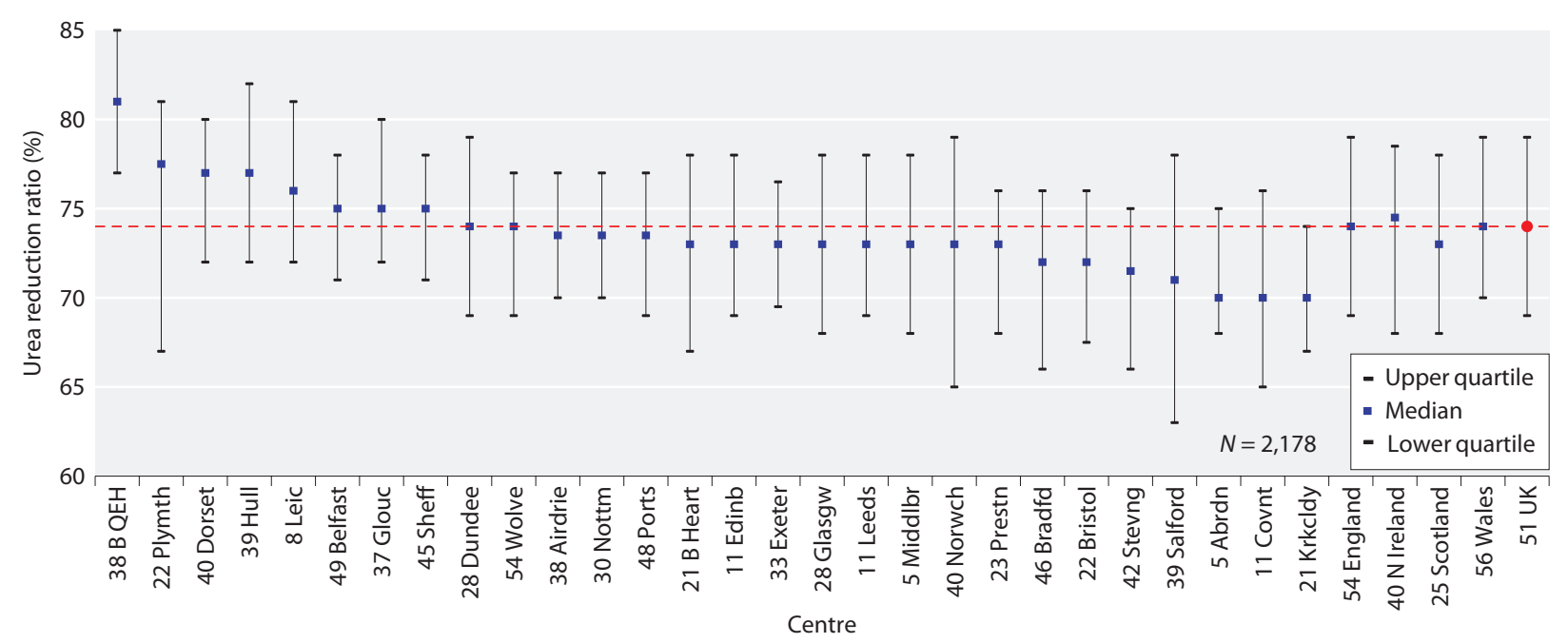

Fig. 7.5b. Median URR one year after starting RRT for incident patients who started HD in 2013

\section{Conclusions}

Although the dose of delivered HD is recognised as having an important influence on outcome in $\mathrm{HD}$ patients treated with low flux HD, it remains unclear as to whether higher urea clearance targets add benefit $[2$, 10]. More recently, higher convective volume clearance achieved with haemodiafiltration has been reported to be associated with improved patient survival [11]. The UKRR does not currently systematically collect data on haemodialysis modality or dialyser flux.

Since 2000, the proportion of UK patients achieving the RA guideline for URR has steadily increased, with more than $88 \%$ of the prevalent 2014 HD population achieving the target, with a median URR of $75 \%$. This increase in delivered URR not only reflects improvements in clinical practice and delivery of dialysis, but also enhanced coverage and quality of the data collected by the UKRR and renal centres over the years. However, it must be acknowledged that not all centres contributed data. This may be due to the difficulties in providing pre and post treatment results, as with many centres now dialysing in outlying satellites utilising evening and overnight shifts, leading to difficulties in establishing pre and post samples by registering different laboratory dates. In addition pre and post urea data has to be cleaned by excluding samples from HD patients admitted as inpatients. Secondly, with the introduction of dialysis machines with on-line clearance, some centres have opted to record $\mathrm{Kt} / \mathrm{V}$ data, which is not currently collected by the UKRR.
Although the URR delivered has increased over time there remained a wide range (74.9-97.0\%) between dialysis centres in the percentage of prevalent HD patients achieving a URR of $>65 \%$. This is likely to reflect genuine differences in the HD dose delivered consequent to both individual patient and centre level factors, although standardised methods for urea sampling are advised [1], inconsistency in sampling methodology for the postdialysis urea sample may also play a part in the variations reported. Understanding individual renal centre practice would be informative, for example some centres may determine residual renal function and adjust dialysis sessions accordingly. Observational evidence supports that preservation of residual renal function is associated with improved survival [12], and reduced extracellular water expansion [13], although there appears to be no benefit maintaining overhydration in patients to try and preserve residual renal function [14]. Some centres may be adopting an incremental approach to the imitation of HD [15], starting patients on twice weekly dialysis schedules or prescribing shorter dialysis sessions, as the median URR for patients initiating dialysis was lower in the first quarter of starting dialysis, and then increased over the course of the first year of haemodialysis, but remained lower than that of prevalent patients established on dialysis, suggesting that dialysis treatments were being adjusted according to residual renal function. Although this may account for some of the differences in dialysis frequency and session times, other centres are known to favour higher blood flows and shorter, but more efficient dialysis sessions. In the future the UKRR 
will collect data from individual patient dialysis sessions, which will allow closer inspection of centre practices.

The median URR was higher for women and more women achieved the URR target in the UK than men. This does not necessarily reflect a greater dose of HD for women, and may simply reflect differences in dietary intake and lower pre-dialysis serum urea values in women $[10,16]$. Paradoxically, although URR may be higher for women, clearance of larger solutes may be lower, as typically women have shorter session times than men $[10,16]$.

The UK government changed reimbursement policy to encourage the provision of more frequent dialysis sessions, by switching to payment for each individual in-centre treatment session [17]. However only four centres reported providing $\geqslant 10 \%$ of patients receiving more frequent dialysis than thrice weekly, and five other centres $\geqslant 5 \%$. This may reflect logistical problems in terms of provision, although the option of more frequent dialysis may also not have universal support from patients.

Although urea clearance is the paradigm for dialysis adequacy, debate continues as to whether urea clearance is representative of the clearance of azotaemic toxin [18,
19]. In addition to clearance of azotaemic toxins, the dialysis prescription also encompasses volume control, sodium and divalent cation balance and correction of metabolic acidosis. As such, basing and evaluating HD dose simply on urea clearance has been criticised, with patient outcomes reported to be improved by longer sessional times independent of urea removal [20] and that clearance of 'middle molecules' may also have an important effect $[11,21]$. However, no consensus has yet emerged on alternative markers of HD adequacy [18]. The UKRR has historically reported URR, predominantly for logistical reasons with the URR being the simplest measure of dialysis adequacy to calculate, and the measure of dialysis adequacy that is most complete when returned to the UKRR. However, limitations of the URR must be recognised [22]. The revised UKRR data set, due to be embedded in the 2016 dialysis centre returns, should help contribute to further improvements in both UK URR data capture, as well as Kt/V reporting in addition to dialysis centre prescription practices.

Conflicts of interest: the authors declare no conflicts of interest

\section{References}

1 UK Renal Association Clinical Practice Guidelines Committee. Haemodialysis, 2009 http://www.renal.org/Clinical/GuidelinesSection/ Haemodialysis.aspx

2 Gotch FA, Sargent JA: A mechanistic analysis of the National Cooperative Dialysis Study (NCDS). Kidney Int. 1985;28:526-53

3 Held PJ, Port FK, Wolfe RA, Stannard DC, Carroll CE, Daugirdas JT, Bloembergen WE, Greer JW, Hakim RM: The dose of hemodialysis and patient mortality. Kidney Int. 1996;50:550-556

4 Locatelli F, Buoncristiani U, Canaud B, Kohler H, Petitclerc T, Zucchelli P: Dialysis dose and frequency. Nephrol Dial Transplant 2005;20:285-296

5 Depner TA: Assessing adequacy of hemodialysis: urea modeling. Kidney Int. 1994;45:1522-1535

6 Kumar S, Khosravi M, Massart A, Potluri M, Davenport A. The effects of racial differences on body composition and total body water measured by multifrequency bioelectrical impedance analysis influence delivered Kt/V dialysis dosing. Nephron Clin Pract. 2013;124(1-2):60-6

7 Davenport A. Differences in prescribed Kt/V and delivered haemodialysis dose - why obesity makes a difference to survival for haemodialysis patients when using a 'one size fits all' Kt/V target. Nephrol Dial Transplant. 2013;28(suppl 4):iv219-23

8 Vanbelleghem H, Vanholder R, Levin NW, Becker G, Craig JC, Ito S, Lau J, Locatelli F, Zoccali C, Solez K, Hales M, Lameire N, Eknoyan G: The Kidney Disease: Improving Global Outcomes website: Comparison of guidelines as a tool for harmonization. Kidney Int. 2007;71:10541061

9 European Best Practice Guidelines Expert Group on Haemodialysis. Nephrol Dial Transplant 2002;17(suppl 7):S16-S31

10 Depner T, Daugirdas J, Greene T, Allon M, Beck G, Chumlea C, Delmez J, Gotch F, Kusek J, Levin N, Macon E, Milford E, Owen W, Star R, Toto
R, Eknoyan G, Hemodialysis Study Group. Dialysis dose and the effect of gender and body size on outcome in the HEMO Study. Kidney Int. 2004;65(4):1386

11 Davenport A, Peters SA, Bots ML, Canaud B, Grooteman MP, Asci G, Locatelli F, Maduell F, Morena M, Nubé MJ, Ok E, Torres F, Woodward M, Blankestijn PJ. Higher convection volume exchange with online haemodiafiltration is associated with survival advantage for dialysis patients: the effect of adjustment for body size. Kidney Int. 2015 Sep 9; doi: 10.1038/ki.2015.264 PMID: 26352299

12 Hanson JA, Hulbert-Shearon TE, Ojo AO, et al: Prescription of twiceweekly hemodialysis in the USA. Am J Nephrol 1999;19:625-633

13 Fan S, Davenport A. Does Loss of Residual Renal Function Lead to Increased Volume Overload and Hypertension in Peritoneal Dialysis Patients? Perit Dial Int. 2015 Dec;35(7):753-5

14 McCafferty K, Fan S, Davenport A. Extracellular volume expansion, measured by multifrequency bioimpedance, does not help preserve residual renal function in peritoneal dialysis patients. Kidney Int. 2014;85(1):151-7

15 Wong J, Vilar E, Davenport A, Farrington K. Incremental haemodialysis. Nephrol Dial Transplant. 2015;30(10):1639-948

16 Spalding EM, Chandna SM, Davenport A, Farrington K. Kt/V underestimates the haemodialysis dose in women and small men. Kidney Int. 2008;74:348-55

17 Vanholder R, Davenport A, Hannedouche T, Kooman J, Kribben A, Lameire N, Lonnemann G, Magner P, Mendelssohn D, Saggi SJ, Shaffer RN, Moe SM, Van Biesen W, van der Sande F, Mehrotra R; on behalf of the Dialysis Advisory Group of the American Society of Nephrology. Reimbursement of Dialysis: A Comparison of Seven Countries. J Am Soc Nephrol. 2012;23(8):1291-8 
18 Vanholder R, Glorieux G, Eloot S. Once upon a time in dialysis: the last days of Kt/V? Kidney Int. 2015;88(3):460-5

19 Daugirdas JT. Kt/V (and especially its modifications) remains a useful measure of haemodialysis dose. Kidney Int. 2015;88(3):466-73

20 Port FK, Wolfe RA, Hulbert-Shearon TE, McCullough KP, Ashby VB, Held PJ. High dialysis dose is associated with lower mortality among women but not among men. Am J Kidney Dis. 2004;43(6):1014
21 Davenport A. How best to improve survival in haemodialysis patients: solute clearance or volume control? Kidney Int. 2011;80(10):1018-20

22 Marshall MR, Byrne BG, Kerr PG, McDonald SP: Associations of hemodialysis dose and session length with mortality risk in Australian and New Zealand patients. Kidney Int. 2006;69:1229-1236 
